\title{
Towards a Typological Account of Pseudo Anglicisms (Illus- trated with Loanwords in Cuban Spanish)
}

\author{
José ANTONIo SÁNCHEZ FAJARDo \\ Universidad de Alicante \\ Carretera San Vicente del Raspeig, s/n \\ 03690 San Vicente del Raspeig, Alicante (España) \\ E-mail: jasanchez@ua.es
}

\section{TOWARDS A TYPOLOGICAL AC- COUNT OF PSEUDO ANGLICISMS (ILLUSTRATED WITH LOANWORDS IN CUBAN SPANISH)}

\begin{abstract}
The wide variety of pseudo anglicisms shows that a number of categories are also found. This article is aimed at sketching these classifications more comprehensively, and to group pseudo loans according to prior studies and revisions (Görlach, 2002; Rodríguez, 2003; Onysko, 2007; Furiassi, 2010; Furiassi and Gottlieb, 2015). These typologies are mainly accompanied by indigenous examples, extracted mostly from differential Cuban Spanish dictionaries and glossaries (Sánchez-Boudy, 1999; Haensch and Werner, 2003 Sánchez, 2017). This research analysis is also aimed at depicting the sociolinguistic causes and semantic evolution of English-induced pseudo loans, based on a compilation of these lexical units, and a brief account of the shifting socioeconomic and political scenarios in Cuba. Some major processes have also been attested and described: 'hourglass-shaped' and 'pyramid-shaped' semantic evolutions of loanwords, and 'metaphorical calquing', which might shed some light on how polysemy and semantic extension, in both source and recipient languages, are involved in the lexical coinage of pseudo loans.
\end{abstract}

KEYWORDS: pseudo-anglicisms; Cuban Spanish; loanwords; sociolinguistics; lexical creativity.

SUMMARY: 1 . Introduction. 2 . Pseudo anglicisms: to be or not to be? 3. Origins of pseudo Anglicisms. 4. Typology of pseudo Anglicisms. 5. Sociolinguistic sources of pseudo Anglicisms. 6. Conclusions.

\section{HACIA UNA TIPOLOGÍA DE LOS PEUDO ANGLICISMOS (ILUSTRADA CON PRÉSTAMOS DEL ESPAÑOL CU- BANO)}

RESUMEN: La amplia gama de pseudo anglicismos nos demuestra que se pueden encontrar una gran cantidad de categorías. Este artículo tiene como objetivo agrupar dichas clasificaciones de una manera más global, y compilar los pseudo préstamos de acuerdo a estudios y revisiones anteriores (Görlach, 2002; Rodrí guez, 2003; Onysko, 2007; Furiassi, 2010; Furiassi y Gottlieb, 2015). Las tipologías vienen acompañadas de ejemplos diferenciales, extraídos en su mayoría de diccionarios y glosarios del español cubano (SánchezBoudy, 1999; Haensch y Werner 2003; Sánchez, 2017). Asimismo, esta investigación se propone describir las causas sociolingüísticas y la evolución semántica de los pseudo anglicismos, partiendo de la compilación de estas unidades léxicas, y de una breve referencia a los distintos escenarios socioeconómicos y políti$\cos$ en la isla. Se han podido verificar y describir algunos procesos de importancia: las evoluciones semánticas en forma de 'reloj de arena' y de 'pirámide', así como los calcos metafóricos, que permiten verificar cómo los procesos de polisemia y extensión semántica, tanto en las lenguas de llegada como las de salida, se relacionan directamente con la creación de pseudo préstamos.

PALABRAS CLAVES: pseudo anglicismos; español cubano; préstamo léxico; sociolingüística; creatividad léxica.

SUMARIO: 1. Introducción. 2. Pseudo anglicismos: ¿Ser o no ser? 3. $\mathrm{El}$ origen de los pseudo anglicismos. 4. Tipología de los pseudo anglicismos. 5. Las fuentes sociolingüisticas de los pseudo anglicismos. 6. Conclusiones.

\section{VERS UNE TYPOLOGIE DES PSEUDO ANGLICISMES (ILLUSTREE AVEC DES EMPRUNTS DE L'ESPAGNOL CUBAIN)}

RÉSUMÉ: La vaste gamme de pseudo anglicismes montre qu'on peut trouver un grand nombre de catégories. Cet article vise à regrouper ces classifications d'une manière plus complète et à compiler les pseudo emprunts selon les études et les révisions précédentes (Görlach, 2002; Rodríguez, 2003; Onysko, 2007; Furiassi, 2010; Furiassi et Gottlieb, 2015). Les typologies sont généralement accompagnées par des exemples différentiels, tirés principalement des dictionnaires et des glossaires de l'espagnol cubain (SánchezBoudy, 1999; Haensch et Werner, 2003; Sánchez, 2017). De même, cette recherche se propose de décrire les causes sociolinguistiques et l'évolution sémantique des pseudoanglicismes, à partir de la compilation de ces unités lexicales, et d'une brève référence aux différents scénarios socioéconomiques et politiques sur l'île. On a pu vérifier et décrire certains processus d'importance: les évolutions sémantiques sous la forme de "sablier" et de "pyramide", tel que les calques métaphoriques, ce qui pourrait permettre de comprendre comment les processus de polysémie et d'extension sémantique, dans les langues cibles tout comme dans les langues source, sont liés à la création des pseudo emprunts.

MOTS CLÉS: pseudo-anglicismes; espagnol cubain; emprunt lexical; sociolinguistique; créativité lexicale.

SOMMAIRE: 1. Introduction. 2 Pseudo anglicismes : ¿Être ou ne pas être? 3. Les origines des pseudo anglicismes. 4. Typologie des pseudo anglicismes. 5. Les sources sociolinguistiques des pseudo anglicismes. 6. Conclusions. 


\title{
Towards a Typological Account of Pseudo Anglicisms (Illustrated with Loanwords in Cuban Spanish)
}

\author{
JOSÉ ANTONIO SÁNCHEZ FAJARDO
}

\section{INTRODUCTION}

The formation and the typology of pseudo loans have puzzled a number of linguists and anglicists (Filipović, 1985; Görlach, 2002; Rodríguez, 2003; Onysko, 2007; Furiassi, 2010; Balteiro and Campos, 2012; Furiassi and Gottlieb, 2015). These units embody the intricacy of linguistic borrowing and native forms' variations, which have been agreeably adopted by target languages.

In this study, a compendium of definitions is provided, as well as the criteria used in the recognition of English-induced pseudo-loans. The analysis of these units represents a novel field within the area of linguistic borrowing, which is largely related to an array of processes, e.g. metonymy, homonymy, eponymy, generic trademark, toponymy, etc. Since this research article, on the whole, is chiefly aimed to relate linguistic borrowing and social pragmatics, the analysis of sociolinguistic motivations and semantic evolution has also been drawn so as to discern the sociolinguistic sources of pseudo-loans. The compilation of lemmas, and a thorough analysis of these lexical units, will reveal etymological and semantic information of the lexico-semantic variants collected. In sum, this empirical study is intended to illustrate how sociolinguistic traits are necessarily involved in the coinage of these English-induced loans.

Thus, the study was carried out in three stages: (i) theoretical framework, (ii) data collection, and (iii) data analysis and categorization. The first stage consisted in the examination of conceptual studies that would allow for a better understanding of a 'pseudo loan'. The following two stages were based on the compilation of these lexical units from three Cuban Spanish dictionaries (Sánchez-Boudy, 1999; Haensch and Werner, 2003; Sánchez, 2017) and the Spanish corpus CORDE, and the reassessment of the lemmas according to word-formation criteria (Furiassi, 2010): autonomous compounding, autonomous derivation, compounding ellipsis, morphological mutation, clipping, reduplication, semantic change, functional change, and hybridity. The use of these descriptive dictionaries also guarantees both a more accurate quantification of the units and a more illustrative analysis of the sociolinguistic traits that underlie the formation of pseudo loans.

\section{Pseudo ANGLicisms: TO BE OR NOT TO BE?}

The study of the influence of English on other languages has been focused on clearly-recognized English loanwords, which is why a number of 
concepts and typologies are anglicism-centered. Corpuses and glossaries indicate that the number of anglicisms and calques visibly exceed that of 'false' anglicisms. However, the latter units are probably the living proof of how linguistic intrusiveness denotes a complex process of semantic change and morphological adaptation, in which the rules of word formation and syntax are nativized. This is, without doubt, the zenith of linguistic borrowing as far as complexity and uniqueness are concerned. "Pseudo anglicisms and hybrid anglicisms are indicators of lexical productivity in the recipient language" (Onysko, 2007: 52).

Traditionally, the word pseudo in 'pseudo-anglicism' has entailed negative connotations, and its drifting apart from concepts such as loans or anglicisms. The coinage of 'English-induced neologism' is probably of greater acceptance, but due to pragmatic reasons, most scholars have adopted the term 'pseudo-anglicism', and this term will be used hereafter.

The analysis of forms and types of pseudo-anglicism brings about the need to reconsider the concept of anglicism. Anglicisms, as they have conventionally referred to, are English-induced forms in the target language, whose phonological, morpho-syntactic, or semantic changes are visibly identified. Thus, not only does the term anglicism encompass borrowed (adapted or not) units directly from English, but it also involves any expression that contains any element that can be recognized through its form, on any different linguistic level (lexical, morphological or phonological), or that takes on a different meaning, keeping the same form (Rodriguez, 2003: 124).

A comprehensive concept has been likewise offered by Cristiano Furiassi, whose main contributions are equally addressed to widen the concept of pseudo-anglicism in present-day lexicographical studies: "a word or an idiom that is recognizably English in its form (spelling, pronunciation, morphology, or at least one of three) but is accepted as an item in the vocabulary of the receptor language even though it does not exist or is used with a conspicuously different meaning in English" (2010: 34).

The above-mentioned criteria have converged in the recognition of native English-induced forms as pseudo-anglicisms as long as their English influence is remarkably perceived by native speakers but not necessarily by English speakers. The attention-grabbing aspect of this phenomenon is the detachment caused by the existing pseudo-anglicisms in the recipient language, and the expected incapability of English speakers to detect the meaning of the existing words, which could be a helpful and delimiting way of looking at the phenomenon from the point of view of the 'monoglot' Anglophone reader or listener (cf. Furiassi and Gottlieb, 2015). What seems irrefutable is that these forms are assimilated and manipulated in any recipient language, and through mechanisms of morpho-syntactic adaptation and semantic extension, fresher units are resorted to (footing 'jogging' in Spanish, Handy 'mobile phone' in German, caddy 'type of trousers' in Polish, etc.) 
The phenomenon of pseudo-anglicization is worldwide, and its so-called pervasive influence might result from a plethora of reasons: the Anglicization of the media, the use of specific jargon, the permeability of a language (i.e. the likeliness of a language to coin these neologisms), the pragmatic connotation conveyed, etc. Cuban Spanish has not been an exception: average 'number of former sexual intercourses', bonche < bunch 'street parties', corring 'the act of running in baseball', dancing 'a night club where people go dancing' < dancing club, etc. Pragmatic features have had an impact on the number and typology of the false anglicisms assimilated, and more importantly, the sociolect these neologisms belong to. Based on the functionality of these forms, it is important to point out that pseudo-anglicisms are bound to be used and perceived more differently than their cognate or equivalent terms in any other speech community, as these entries operate in an unlike cultural and linguistic environment and tend to fulfill different needs.

The primary challenge is to approach a clear-cut distinction between pseudo-anglicism and other similar processes. From a normative perspective, pseudo-anglicisms might undergo different linguistic changes (graphemic, phonological, morpho-syntactic, or semantic). These changes coincide partly with the ones described in other linguistic anglicization processes: loanword, hybrid, calque, semantic loan (cf. Furiassi et al., 2012), but a differentiating trait stands out: 'false' or 'pseudo' loans are nonexistent in the source language. Thus, adapted direct loanwords (blúmer 'female underwear' < bloomer, esquedo < schedule) are not pseudo-anglicisms because they do exist in English, yet their resulting forms have been morphologically and graphemically modified. Therefore, the lack of English-ness does not necessarily involve a disruption between two paronyms; the loss of some of the features is associated with adaptation processes (chiefly graphemic and phonological).

Occasionally, English and the recipient language inventory evolve diachronically and loanwords might derive into pseudo-anglicisms because their corresponding English paronyms become unused. This is an infrequent phenomenon, and it is linked to the pragmatic features of these forms: gascar < gas car, creche 'nursery and pre-school center' < crèche (in American English, the meaning of nursery center and pre-school center is not attested).

\section{ORIGINS OF PSEUDO ANGLICISMS}

Once the distinguishing features of 'false' anglicisms are clarified, there exists a need to comprehend how these lexical units come into light. There is not a single process involved; on the contrary, a few word-building mechanisms might intervene: (1) a foreign element is borrowed and nativized, or translated, in the recipient language (foreignness traits are not easy to detect by recipient language speakers) as in bisne 'illegal business'; (2) a foreign element is borrowed and not adapted (foreignness traits are easily spotted 
by recipient language speakers) as in dancing 'discotheque'; (3) a native element is attached to foreign morphological or phonological features as in corring 'run'; (4) foreign elements are combined in the recipient language unnaturally as in fit-doing 'ok'; (5) nativized anglicisms undergoing extension of meaning and leading to homonyms, whose newly-grown sense detaches completely from its original English paronym as in fotingo 'buttocks' (originally from the slogan 'foot it and go', then it was used for old cars).

The latter might be arguably considered a 'false' loan because this semantic process takes place within the recipient language, i.e. Cuban Spanish, and not as a result of language contact. Therefore, taking into consideration that intra-linguistic sense-shifting processes (homonymy, polysemy, metonymy, etc.) do not involve any code-switching or borrowing mechanisms might change our current perspective towards pseudo-anglicization. Let us take the example of bisne: initially, the word bisne < business was borrowed to denote any 'activity of making, buying, or selling goods or providing services in exchange for money' (Merriam Webster's Dictionary); once the loanword was coined, it evolved into 'illegal business' due to pragmatic and semantic features. Obviously, processes (1) and (5), as described above, are involved in the coinage. Since our earlier, and probably wider, definition of pseudo-anglicisms implied any borrowing whose meaning in the recipient language does not coincide with its corresponding paronym in the source language, the term pseudo-anglicism is used to denote these intralinguistic forms as well.

Furiassi and Gottlieb (2015) refer to a variety of factors involved in the adoption of 'false' anglicisms: language economy, in which brevity is key to understand the coinage of shortened forms such as dancing 'dancing club or discotheque', center 'center-field'; or the "taste for the exotic, the charm of a foreign language, and the glamorous quirk of being creative and playing with language are the core motivations for the birth of false Anglicisms" (Furiassi, 2010: 62-63).

In the case of mechanism (4) described above, it is relevant to point out that it is another recognizable source of anglicisms of great importance and complexity due to the 'autonomous compounding' (Rodriguez, 2013: 128) these foreign elements go through. Rodriguez outlines a series of 'false' anglicisms in Spanish of this kind: recordman/recordwoman (replacing recordholder in English), boxman (instead of boxer), etc.

\section{TYPOLOGY OF PSEUDO ANGLICISMS}

In the previous section, an introductory account of the sources of 'false' anglicisms was provided, which might help us understand the theory on which the following typology is based.

An interesting classification of pseudo-anglicisms was introduced by Görlach (2003: 62), in which four groups have been identified according to the 
level affected: (a) spelling: when native words are spelt as if they were English; (b) pronunciation: when native words are pronounced as if they were English; (c) morphology: when derivatives or compounds, not recorded in English, might conform with English patterns; (d) meaning: when English words are used in unnatural contexts. This hands-on grouping suggests the extent to which false anglicisms are traceable.

In the study of these lexical units, Rodriguez (2013: 125-146) summarizes the five major types of pseudo-anglicisms in Spanish, and details further word-building subgroups. The classification of these borrowed forms might shed some light on how the adaptation process and semantic motivation are linked. Understanding the wide ratio of occurrence of this process is probably one of the most challenging targets of current studies on linguistic borrowing.

According to Rodriguez, there are five comprehensive groups, which coincide with prior classifications of anglicisms in terms of the linguistic levels involved:

a) Lexical pseudo-anglicisms: recordman/-woman 'recordholder', footing 'jogging'; corring 'run'.

b) Morphological pseudo-anglicisms: biuti < beautiful (people), lunchera < lunch box, shopping 'store' < shop.

c) Semantic pseudo-anglicisms: slip 'male underwear', mitin 'street protests' $<$ meeting.

d) Phonological pseudo-anglicisms: manigüiti 'theft' < money, jaibolear < high ball, niquel 'coin' < nickel.

e) Syntactic pseudo-anglicisms: sugar brown < brown sugar ${ }^{1}$ (adjective + noun order is modified).

Onysko (2003) argues that "the division of pseudo loans into lexical, morphological, and semantic pseudo loans blurs the difference between semantic and morphological adaptation of anglicisms (in the recipient language) and the creation of pseudo anglicisms as lexical units irrespective of an English model" (53). He differentiates those German pseudo loans appearing as regular borrowing because they derived from English models as in Profi, Pulli (back formation from professional and pullover), and those like Handy or Dressman, which do not relate directly to English models. Based on this distinction, Onysko highlights the functional capabilities of German as far as word formation is concerned.

Other types of classifications describe these units as constructs derived from specific linguistic processes. It is not infrequent to find some forms resulting from the natural mix of two or more processes of this kind. Some

\footnotetext{
${ }_{1}^{1}$ Example in European Spanish, retrieved from Rodríguez (2013).
} 
of these classifying arrangements respond to the need of detailing the etymology of words and the nature of the mechanisms involved (Furiassi, 2010):

1. Autonomous compounding: these forms were referred above as a productive source of pseudo loans, especially in Spanish. Autonomous compounding results in the combination of two autonomous lexical units in English, which combine in the recipient language. In Cuban Spanish, this mechanism is infrequent, and few cases are attested: fit-doing 'ok' < fit + doing, gascar < gas + car. These compounds are most likely motivated by anglicized patterning (as in -man or -woman) or just 'gibberish' associations (as in fit-doing). Other examples: star bout < (boxing) bout, chorpan/shorpan 'bermuda' < short pants.

2. Autonomous derivation: these derivatives are probably the most visible forms of pseudo loans in Spanish, especially in Spain, in which an already-existing anglicism undergoes an English derivational process resulting in a non-English derivative: championismo < champion + ism(o), footing, drinking. The present-day tendency to borrow the process, not the bases involved, has been widely resorted to in the media, especially in European Spanish: kitchening, balconing, edredoning, sofing, puenting ${ }^{2}$ are current pseudo derivatives characterized by attaching a native base to the -ing form. The resulting units convey contemporaneity, humor or discomfort.

The attachment of diminutive derivational suffixes to anglicized bases in $\mathrm{Cu}-$ ban Spanish is not frequent, but these nominal forms constitute a living proof of the productivity of loanwords within a target language. These forms are usually associated with the suffix -ito $(a)$ as in shorcito < shorts, pulovito $<$ pullover, babyto < baby, blumito < bloomers. These forms are clearly English-induced since their resulting derivatives are a blend of a foreign base and a native suffix. These derivatives are clearly not pseudo-anglicisms since they do convey the same sense, but with alterations in the referent: pulovito, blumito, and shorcito are most likely denoting children's garments whereas their English paronyms are used for both adults and children.

3. Compounding ellipsis (or breakage): this process is characterized by the ellipsis of one component (or more) of the borrowed compounds. The remaining units are kept in the recipient language and they undergo a redefinition of their syntactic functions, as opposed to their original forms in English: center (field) 'baseball position', shopping (center), living (room set), volley (ball), floppy (disc). Curiously, -ing forms might convey different semantic and syntactic functions depending on the Spanish variants and contextual motivations: shopping in Cuban-American Spanglish is a

\footnotetext{
${ }^{2}$ Examples found in European Spanish only.
} 
proper anglicism with the meaning 'to visit places where goods are sold in order to look at and buy things' (Merriam Webster's Dictionary) whereas in Cuban Spanish it is classed as a pseudo loan meaning 'a store in which products can be bought with dollars'. Similarly, living in Cuban-American Spanish could mean 'the cost/style of living' whereas in Cuba it does denote 'a set of living room (furniture)'. Both shopping and living are described as polysemous loans because of the word-building processes undergone and the variant involved. Other examples of compounding ellipsis are: rolling < rolling hit, cutout / katao/ < cutout box.

4. Morphological Mutations: these changes are associated with morphological shifting, i.e. "the replacement of the original ending by a more expressive, resounding, and productive one like -ing suffix" (Rodriguez, 2013: 133). The examples attested in Rodríguez's article are not abundant, but they show how these lexical units are formed: dancing < dance, leasing < lease, face-lifting < face-lift, drinking < drink, etc. In Cuban Spanish, some of these examples are also found but they might convey a different sense. In the case of dancing, this word primarily denotes 'a place for dancing' or 'discotheque', but not necessarily 'the act of dancing'. Therefore, this form in Cuban Spanish does not derive from the verb dance, but it results from compounding ellipsis (dancing club), similarly to the same process undergone by shopping (< shopping center). However, drinking is probably an exceptional case in Cuban Spanish because its sense of 'the act of drinking alcohol' coincides fully with its akin form in English, so it shouldn't be referred to as a pseudo loan.

A distinguishable illustration of morphological mutation is also found in baseball terminology, which is in synchrony with Spanish speakers' preconception towards the suffixes -er and -ing. The former (as well as its allomorph -or) is commonly perceived as agent-related (big liguer 'someone possessing high qualifications and/or skills' < big league) whilst the latter could be used for different types of references: places (dancing), action (drinking), and appearance (looking). One of the baseball-related examples is rolling, which is 'a type of hit on the field, not a bouncing one'. This mutated coinage derives from roller, which also exists in Cuban Spanish through the adapted direct borrowing role. Both forms, role and rolling, coexist in Cuban Spanish. Regarding the word looking (low prestige), the etymology of this form is uncertain, and generally used in native phrases: tener un looking 'to look good'. It could either mutate morphologically from the verb look or derive through omission or ellipsis from the compound good-looking. One of the interesting features of these mutations is that they are obviously accompanied by morphological modifications as well as syntactic changes: the forms drinking and looking are not seen isolated in a given utterance; they call for additional native forms to convey a specific semantic structure (e.g. darle/meterle al drinking, tener un looking). 
A typical graphemic deviation (or mutation) induced by English is present in those words spelt with $c$ (cake/kei, pancake/pankei, cuáquer/kuaquer). These doublets coexist in Cuban Spanish and their differentiation depends on the register they are used in. The case of recentin 'a type of cow that has just given birth' is an isolated one. Its English influence is highly evident (< recent) but not the origin of its attached suffix. It could be a patterning construct of adjective recent and suffix -ing (recenting). Not only would this derivative prove the polysemous nature of suffix -ing in Spanish but it also adds a deep-rooted sense of Englishness to its grapheme and sound.

5. Clipping: at times, loaned words undergo alterations or shortening of their original forms, which might lead to nativized clippings, nonexistent in English. This process is particularly motivated by phonological adaptation or language economy: aerobic < aerobics, happy end (< happy ending), bodyboard (< bodyboarding), mountain-bike (< mountain-biking), skateboard (< skateboarding), snowboard (< snowboarding), surf $(<$ surfing), windsurf $(<\text { windsurfing })^{3}$. Interestingly, clipping and mutation are both morphological alterations of loan words; their difference relies on the ellipsis (clipping) of suffixes or grapheme clusters, or the addition (mutation) of suffixes to the bases borrowed.

Clipping and compounding ellipsis are equally motivated, but the latter purely describes the omission of compound bases, not their constituent suffixes or clusters. Occasionally, both processes might take place in a single loaned word: windsurfing is clipped into windsurf, and then its last base is omitted as in wind. This might exemplify the overlapping nature of these word-building mechanisms, and set formation patterns in terms of etymology and morphology.

Apocopes are the most frequent type of shortenings found (happy end, windsurf, etc.), but initial part of words can be likewise clipped (apheresis) as in queque 'a crunchy pasty' < pancake (also a reduplication). An unusual case of mutation is also linked with the process of adaptation: middle-position clusters of consonants or vowels are dropped, resulting in a 'necessary' adapted shortening: cotel 'a fruity punch' < cocktail (English cluster - ck- is omitted).

In Cuban Spanish, a number of clipped pseudo loans are also observed, especially those shortenings in final position (apocopes): pun 'a pointed hairdo' < punk, par (cable) 'the cable having two paired wires' < paired (cable).

At times, some anglicisms might be thought as clipped constructs due to their rather imperceptible English forms: siol < short stop, tubey < two-base hit, tribey < three-base hit. These resulting units are the product of morphological fusion of composites, most likely due to phonological reasons.

\footnotetext{
${ }^{3}$ Examples in European Spanish, retrieved from Rodríguez (2013: 135).
} 
6. Reduplications: historically, Cuban Spanish has been flooded with reduplications, which are characterized by the repetition of the same graphemic form for the sake of emphasis, or humorous connotations. These loaned pseudo compounds are built within the recipient language, and some of the forms have outlived their original loans: tifi-tifi 'theft' < thief, soqui-soqui 'fornication' < to suck, napi-napi 'sleep' < to nap.

7. Semantic changes: this is probably one of the most productive wordbuilding processes as far as pseudo-anglicisms are concerned. It refers to the semantic shifting undergone by English words within the recipient language through homonymy, metonymy, polysemy, etc., leading to English-induced coinages whose semantic structure is clearly detached from their corresponding English paronyms. The diachronic acquisition of new senses is a frequent process, which results from the natural tendency to make use of the accessible vocabulary stock. The newly-coined lexicosemantic variant (LSV) is easily distinguished because its loaned form was earlier acquired by the recipient language under a new sense. The unprecedented LSV becomes thus a pseudo loan, whose form coincides with its English paronym but its sense clearly detaches from the original one. This study reveals that a few mechanisms might intervene in the formation of a new LSV:

a. Metonymy: this phenomenon is highly productive with regard to lexical borrowing. As to pseudo-anglicisms, the commonest process refers to the borrowing of trademarks' names and their corresponding coinages of the products they stand for: $f a$ 'detergent' < Fab, péter 'a milk chocolate bar' < Peter Paul, frigidaire 'fridge' < Frigidaire, chevy 'an old car' $<$ Chevy/Cheverolet.

Metonymic processes are also present in words denoting places in which a service is provided, or a specific product is sold. This is particularly frequent in Cuban Spanish, and these forms are usually adapted to Spanish morpho-syntactic features: piquera 'a taxi rank' < pick-up (passengers are picked up there), maltera 'a malt shop' < malt, donera 'a donut shop' < donut (in Cuban-American Spanish), ponchera 'a car garage specialized in flat tires' < punch. In European Spanish, Rodriguez (2013: 136) distinguishes the use of burger 'hamburger' and burger 'hamburger shop'. There exists a gender shift in both forms: the former is feminine (probably due to its Spanish synonym hamburguesa) and the latter is masculine, which might indicate its connection with burger chains such as Burger King, MacDonald's, etc. Occasionally, metonymic forms are used to denote the purpose of the action or the activity it is related to (ajustadores 'bras' < adjusting brassieres; combinada 'machinery used for cutting and processing sugar canes' < combine harvester; tenis 'sport shoes' < tennis shoes). 
b. Metaphorical: the metaphorical extension of meaning in loanwords is motivated by: physical traits of referents, humorous connotation of the vernacular, or merely denotation. Metaphors are responsible for the transfer of English words' semes into loaned lexical units, most of which have lost visible relationship with their original paronyms: filin 'a ballad-related music style' < feeling, mitin 'a street protest' < meeting, bonche 'an informal gathering in which jokes are told and tricks are played' < bunch, bate 'a large penis' < bat.

Baseball-related words or phraseology are highly influenced by metaphorical transfer of meaning, especially in the formation of vernacular expressions (Sánchez, 2016a: 20-22): hacer swing 'to pay attention to someone or something' < to swing, poncharse 'to get frustrated' < to punch-out, tener average 'to be promiscuous' < average.

At times, loans undergo semantic changes through more than one process involved: chevy (or cheverolé) was firstly assimilated as a car trademark; then through metonymy, the word is used to signify old American cars (especially those built before 1959); and through a metaphorical transfer of original Chevy cars, the word is likewise used to call people 'having large ears' as in ser un chevy (Chevies were known for their wide side doors).

c. Synecdoche: these forms are named after smaller segments of a much bigger concept: pipa < pipe is a truck having a special container attached, or pipe, which is a long hollow tube for carrying water, gas, etc.' (Merriam Webster's Dictionary). Thus, the truck is named after the container attached. The word bafle < baffle is another example: it denotes in Cuban Spanish the loudspeakers used to make sound louder, and this lexeme comes from 'the screen used to control the flow of the outcoming sound' (Merriam Webster's Dictionary).

d. Eponymic: these are common nouns whose origin relies on proper English names: meri popin 'globe-trotter' < Mary Poppins, roquefeler 'very rich person' < Rockefeller. Interestingly, the formation of these nouns is not as productive in contemporary Cuban Spanish as the formation of proper names based on English common nouns: Meivi < maybe, Usanavy < USA Navy, Danyer < danger.

In the case of the European Spanish, Rodriguez (2013: 139) illustrates this process through a number of examples and their corresponding etymologies: rebeca 'a type of buttoned jumper' < Rebeca (a film by A. Hitchcock, in which the lead actress wears a similar piece of garment), cárter 'crank-case' (an engine cover invented by J. Harrison Carter), etc. Interestingly, carter is also used in Cuban-American Spanish with the meaning of 'peanut'. Its etymology dates as early back as the Carter-Reagan presidential campaign, in which Carter was known for harvesting peanuts (Sánchez-Boudy, 1999: 155).

In Cuban-American Spanish, owing to its exposure to American-related names and culture, eponyms of this kind are recurrently found: 
ser el Dr. Chol 'to be someone's support' < Dr. Scholl (trademark), ser una orfan Ani 'to complain a lot' < Orphan Annie (a TV series' character), jiménez 'FBI agents' < G-men (Cubans would pronounce it as /himen/ and spell it as jimen).

e. Toponymic: these English-induced units are characterized by resulting from English place names: bayú 'brothel' < Bayou (a swampy area in the Southeastern part of the US, which is thought to be linked to the city of Havana through steady trading routes); yuma 'a US citizen' or yuma 'the US' < Yuma (a city in Arizona, in which Western films were often based in). There are a number of anglicized buildings' names, especially in Havana, whose nativized grapheme or pronunciation is clearly visible at times: tencén < Ten Cent, sia < Sear, sanyón < Saint John. Hershey (pronounced / hersi/) 'a small town relatively near Havana' was founded by Hershey (a chocolate maker), and its name has remained ever since.

A case of sport-related toponymy is derbi or derby, which exists in both variants of Spanish, Cuban and European Spanish, and its etymology is the English city of Derby, where outstanding horse-riding competitions have taken place. In Cuban Spanish, it is used to denote a competition in which lead hitters compete as to the number of home-runs hit, whereas in European Spanish it is commonly found as a particular match between two same-city football teams (Barça-Espanyol, Real Madrid-Atlético).

f. Generic trademark: not surprisingly, these oft-quoted proprietary eponyms, are the product of a blend of a long-standing transculturation process from 1902 to 1959, and a post-1959 migration to the US. Therefore, the coinage of genericized trademark has never stopped: fab, chevy, péter, frigidaire (see Metonymy section above), singer 'sewing machine' < Singer, yale 'door locks' < Yale, irombeer 'orange fizzy drink' < Ironbeer, centropen 'ink pen' < Centropen, cuáquer 'oatmeal cereal' < Quaker, bendix 'A gear based on a spiral drive mechanism of an inertia-type starter' < Bendix, licra 'leotard' < Lycra.

g. Hypernymic: these forms result from the transition of hyponymic forms to more hypernymy standards: láguer 'beer' < lager (a type of beer that is light in color and is aged at cool temperatures); frizer 'fridge' < freezer (a type of refrigerator used for freezing certain types of food). Note that these forms (láguer, frizer) do exist in English as hyponyms whereas in Cuban Spanish they are clearly identified as hypernyms.

8. Functional changes: occasionally, pseudo loans result from a shifting of syntactic functionality. This is easily illustrated through baseball-related forms: center-field, right-field, infield, left-field (positions of players within the infield), are also used in Cuban Spanish to denote the players (agent) 
instead of their 'logical' English constructs: center-fielder, right-fielder, infielder, left-fielder. The 'agent' trait or member group (as in baby-boomer) is traditionally provided through -er suffix. However, "in spite of its omnipresence in English morphology, the ordinary reader does not possess this awareness, which explains not only its omission (...) but also the occasional use of certain anglicisms having this ending and lacking such a meaning" (Rodríguez, 2013: 143).

The nominalization of certain adjectives is also another example of functional changes: a strapless or estráples 'a top without straps' is originally taken from the adjectival form, i.e. strapless blouse/top; frozen 'ice cream served through rationing machines', and whose origin is probably explained through the ingredients used: frozen milkshake; doble < double play implies a compound ellipsis and a modification of grammatical function, which is why grammatical pseudo loans are at times accompanied by other types of morphological changes.

9. Hybrid anglicisms: in this category, we should distinguish two types of pseudo loans: (a) English-induced compounds, in which one of the elements is borrowed from English (and sometimes adapted), and the other element is a native one; (b) English-induced phrases, consisting of one (sometimes more) English unit and native structures and syntax. The former is easily spotted in Cuban Spanish due to its relevant humorous nuances: pipi-room 'toilet', manigüiti 'theft' < money. The latter denotes a process of calquing, in which one of the elements is borrowed and kept whereas the rest of the phrase components are syntactically and morphologically native: juego de living 'living-room set', al bate < at bat, meter jonrón 'to hit a homerun' < homerun, linea de foul $<$ foul line. These phrases are particularly productive in Cuba and they are arguably considered pseudo loans because the process is primarily based on a semicalquing process, whereby one of the lexical units is not translated. The unchanged English unit is not modified semantically, but syntactically some modifications might be observed: living < living-room denotes both the room and the furniture.

\section{SOCIOLINGUISTIC SOURCES OF PSEUDO ANGLICISMS}

The aforementioned classification of pseudo-anglicisms reveals that these units might comply with more than one word-formation pattern. These processes also show underlying sociolinguistic motivations, related to native speakers, not necessarily the referent. One of these motivations is linked to the association of English words, or an English word with native bases, owing to an English morphological and phonological resemblance: manigüiti 'theft', fit-doing 'ok', gratindei 'free', puchindrün 'absent-minded'. These are not frequent coinages and they belong to low sociolect.

Interestingly, of the total of thirty-one entries tagged as 'vulgar' in dictionaries or glossaries (Santiesteban, 1985; Sánchez-Boudy, 1999; Haensch 
and Wegner, 2003; Sánchez, 2017), twenty-six have been identified as pseudo loans (e.g. fachar 'to steal' < to fetch, medir el antifrizer 'to be homosexual' < antifreezer, farmer 'someone who fornicates continuously'). Of the 143 English-induced colloquialisms or slang words identified, 122 are pseudo anglicisms (bobiney 'mess and dirt left after some spilled liquid' < bobbinet, bacha 'a noisy get-together in which people drink and dance nonstop' < batch, bisne 'an informal love affair, particularly kept in secret' < business). This suggests that pseudo borrowing is essentially present in $\mathrm{Cu}-$ ban Spanish low sociolect.

Another factor is necessarily connected with the unfamiliarity with English syntax, morphology, or semantics. The resulting constructs show grapheme or phonological 'ungrammaticality': pig < pigskin, pun / pun/ 'hairdo' < punk, quiropedista 'chiropodist', recentin 'a cow that has just given birth'; or semantic one: rentacar 'hire car' < rent-a-car, show 'funny', wild 'not having concentration' < wild pitcher. Semantic alterations usually occur within the recipient language, particularly through the transfer of metonymic or metaphoric traits. The extension of meaning does not necessarily imply certain knowledge of English, but a familiarity with the English word in particular, and its corresponding meaning. This explains why low sociolect is strangely fraught with direct anglicisms, not as much as calques.

In Cuban Spanish, a significant number of pseudo-anglicisms, if not most of them, are related to sociolinguistic variations. Earlier Neocolonial coinages (1902-1959), once being assimilated into the language, have extended their meanings in post-1959 times (Sánchez, 2016b: 38): fotingo < foot it and go (from the hyponym car to old car), party (from 'a refined cocktail' to 'an informal gathering'), bonche < bunch (from the quantifier 'a group of' to 'an informal group of people mocking and having fun'). These oftquoted transitions denote a progressive shifting of semantic traits. Those lexical units adding extra connotational meaning to their original sense are most likely to be found in Cuban Spanish. This connotation change might be linked to hilarity, low sociolect, unfamiliarity with native forms, etc. These fluctuations occurring within the recipient language, though considered clear-cut cases of pseudo-anglicisms, are the product of long-existing 'natural' processes of polysemy or homonymy, which could result from the assimilation of a one-sense lexico-semantic variant, not the complete lexeme. To illustrate how this extension of meaning occurs, two instances are charted hereafter (Figures 1 and 2). 


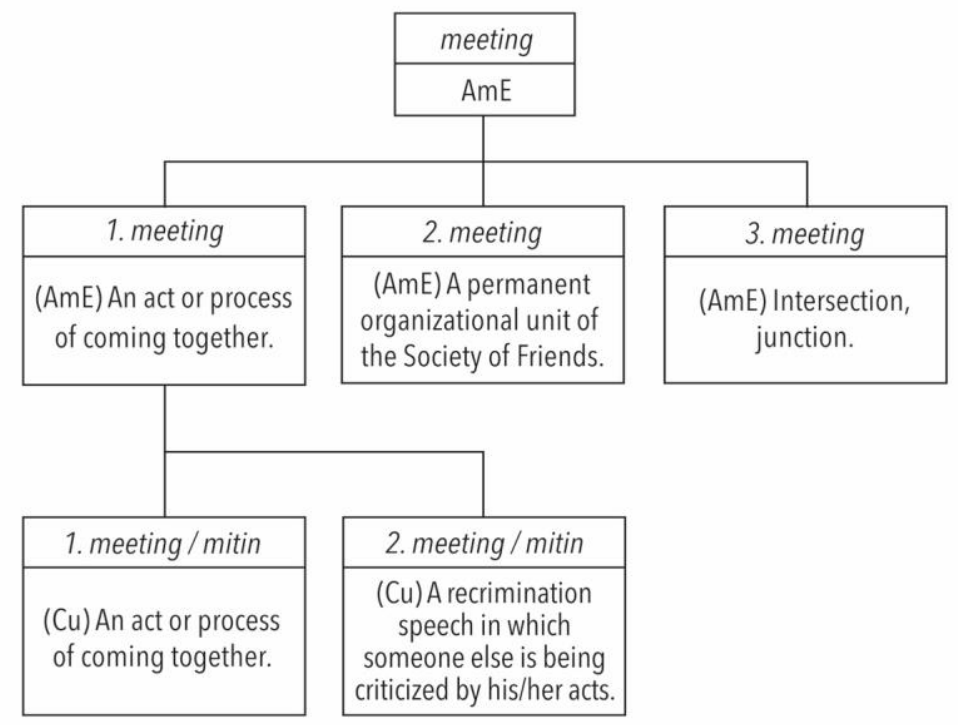

Figure 1: 'Hourglass-shaped' semantic evolution of loanwords

In the case of meeting (Figure 1), three global senses are attested by Merriam Webster's Dictionary. Sense 1 'an act or process of coming together', or lexico-semantic variant 1 (LSV-1), is entirely assimilated in the language, and thus adapted (miting, mitin):

Gran Miting: Siendo las ocho y media de la noche, toda la concurrencia se dirigió al parque local y frente a la casa rectoral se realizó el miting, que fue amenizado por la banda de Torrens. (Diario de la Marina. February 20, 1947, p.6)

Tu padre también tenía un viaje proyectado a la Isla Grande, al puerto de Fajardo, me parece, donde los nacionalistas iban a celebrar un mitin. Él no era muy amigo de asistir a mítines, pero corrian rumores de que iban a matar al jefe de todos ellos. [CREA]

As noted, only one LSV is borrowed, which reflects a one-sense assimilation. LSV-1 is thus the primary product of borrowing in this first stage. In Cuban Spanish, two senses are found in the case of mitin: a) (direct borrowing) an act or process of coming together, as shown earlier; b) (pseudo-anglicism) a recrimination speech in which someone else is being criticized by his/her acts, as in:

El pasado 4 de noviembre en horas de la tarde la policía politica aglutinó frente a su casa unas 500 personas para darle un mitin de repudio y además pintar la fachada para eliminar los carteles. ("Foto-reportaje sobre mitin de repudio a Ivis Rodríguez González", pinceladasdesdecuba.com, 11/14/2011) 
This post-1959 loan is occasionally linked to some political connotation, but it is likewise found in the vernacular with the meaning of 'telling someone off' as in darle un mitin a alguien.

This diagram shows how semantic evolution of loanwords, especially pseudo-anglicisms, may occur in any given recipient language. This 'hourglass-shaped' process describes the assimilation of an LSV from a polysemous English word. The resulting loan necessarily undergoes an extension of meaning, leading to polysemic units in the recipient language.

This diagram contrasts with 'pyramid-shaped' processes, characterized by departing from a one-sense English lexeme, and resulting in a number of LSVs in the recipient language. This is not frequent, and it is mostly found in lexical units borrowed from technical or specialized lexis (see Figure 2).

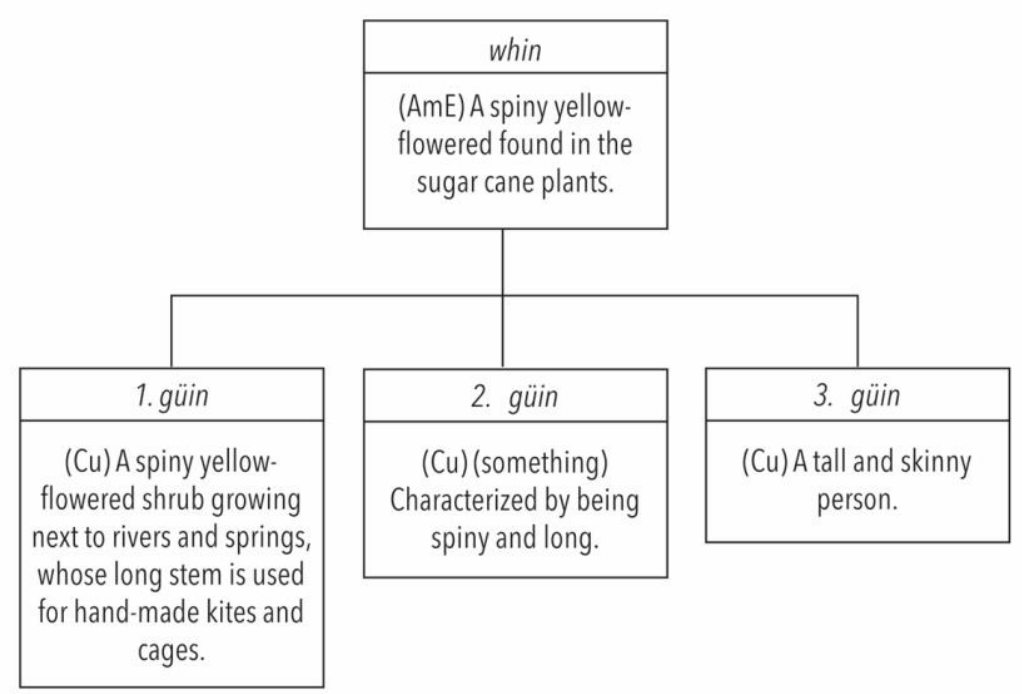

Figure 2: 'Pyramid-shaped' Semantic evolution of loanwords

The adapted borrowing güin not only has undergone a metaphorical transference of meaning, but has also been attached to derivational suffixes in Spanish to nativize the loan: güinal 'a place full of güines', güinero 'someone who collects güines'. Onomastically speaking, it has even been adopted to name a middle-size town not far from Havana: Güines.

A similar frequent patterning is also visible in indirect lexical borrowings. Thus, the stricter sense is a calque, chiefly a loan translation or loan rendition, whose meaning is noticeably shifted into a metaphorical sense (see Figure 3). This type of lexico-semantic variant has been classed as metaphorical calque, and it denotes a recurring process of semantic variation. Both senses have been extracted and detailed in the data-collection stage 
because they are considerably relevant to study semantic shifting or polysemy/homonymy in lexical borrowing.

\section{coger fuera de base}

$v$. trans., sport 1 In baseball, to catch out a baseball runner for not being on base.

Teniendo en cuenta todo lo que hemos hablado, si creo que este equipo de dirección ha dejado mucho que desear y sino busquen cuantos corredores nos han cogido movido fuera de base, cuántos han sido mandado para home. ("Serie nacional: los toros según Rolando Hernández", adelante.cu, 22/09/2015)

v. ph., colloq. 2 To surprise someone when he/she is doing something inadequate.

Un silencio dudoso. A mí me ha dado pena. Los cogió fuera de base esta entrevista. ("Amaury Pérez habla sobre la entrevista al Cardenal Ortega", cubared.com, 05/09/2015)

Figure 3: Lexico-semantic variants of coger fuera de base

On the whole, metaphorical calquing is the product of translation and polysemy. The resulting constructs are probably the least easily-perceived forms by English speakers, and they are widely found in Cuban Spanish: correr para tercera base 'to resort to mockery and evasion to do something' $<$ to run to third base, base por bolas 'to allow someone to get away with it' < base on balls, esquina caliente 'a place in which controversial issues are discussed' < hot corner, bombero 'someone capable of solving problems' < fireman. A total of seventy-four metaphorical calques have been compiled, accounting for nearly eight percent of the English-induced lemmas extracted. The majority of these phraseological units are baseball-related, and their resulting forms are either slang or colloquialism.

False loans and metaphorical calquing share a great deal of similarities. The former units are signifier-centered, i.e. a loanword is assimilated into Spanish but its meaning differs from its English counterpart. The latter process depicts the mechanism of semantic borrowing, i.e. signified-centered, and its variations within the target language system.

\section{Conclusions}

Throughout the research, great importance has been given to the phenomenon of pseudo-anglicization owing to the ever-increasing number of coinages and to the concept of lexical productivity. The wide-ranging classifications have confirmed the complexity and variability of these lexical units in Cuban Spanish. Unlike the European variant of Spanish, autonomous derivation cases (e.g. -ing added to a native base such as puenting) are not productive, and the number of generic trademark pseudo-loans is more limited or unused, entailing a semantic shift occurring after 1959 with the triumph of Cuban Revolution.

The compilation of pseudo-loans in Cuban Spanish dictionaries and glossaries have suggested that the majority of these forms are tightly linked with low sociolect. In particular, $85.3 \%$ of the pseudo-anglicisms found in these sources are colloquialism or slang. The existence of ungrammaticality in 
pseudo-anglicization and its diastratic preference imply that a familiarity with English is not always necessary in the cases of lexical productivity and semantic shifting.

An important finding in the study of pseudo loans is the understanding of semantic extension, namely polysemy and homonymy, within the recipient language. These anglicized units result either from the assimilation of a lexico-semantic variant, i.e. one sense, or from the complete lexeme. The former process has been labeled as an 'hourglass-shaped' semantic evolution, sketching the primary source of borrowing and its resulting homonyms and paronyms. The latter, though infrequent, has been alternatively named 'pyramid shaped', and it denotes the assimilation of a lexeme into the target language. The processes of semantic extension and transference of meaning take effect within the target language, and their constructs are expectedly unidentifiable by an English speaker.

Likewise, the coinage of a number of metaphorical calques, which have been particularly attested in baseball-related lemmas, has indicated that homologous processes, i.e. calquing and polysemy, are also responsible for the semantic complexity Cuban pseudo-anglicization is characterized by.

A sociolinguistic revision of pseudo anglicisms shows that their formation and usage are related with distratic and diaphasic variations. On the whole, Cuban Spanish pseudo loans are mostly used in low sociolect in contemporary Cuban Spanish. However, these units have been coined as early back as Neocolonial period (1902-1959), which shows how significant the semantic transition of these units has been, and how their connotation reassignment is linked to ruling sociolinguistic conditions.

\section{REFERENCIAS}

BALTEIRO, I. \& CAMPOS, M. A. (2012): "False anglicisms in the Spanish language of fashion and beauty", Ibérica, 24, pp. 233-260.

FILIPOVIĆ, R. (1985): "Pseudoanglicisms in European languages", Ursula Pieper y Gerhard Stickel (eds.): Studia Linguistica Diachronica et Synchronica. Werner Winter Sexagenario, New York/Berlin: De Gruyter, pp. 249-255.

FURIASSI, C. (2010): False anglicisms in Italian, Milano: Polimetrica.

FURIASSI, C. \& GOTTLIEB, H. (eds.). (2015): Pseudo-English. Studies on False Anglicisms in Europe, Berlin: De Gruyter Mouton.
FURIASSI, C., PULCINI V. \& RODRÍGUEZ, F. (eds.). (2012): The Anglicization of European Lexis, Amsterdam/Philadelphia: John Benjamins Publishing Company.

GÖRLACH, M. (2003): English Words Abroad, Philadelphia: John Benjamin Publishing Company.

HAENSCH, G. \& WERNER, R. (2003): Diccionario del español de Cuba, Madrid: Gredos.

ONYSKO, A. (2007): Anglicisms in German: Borrowing, Lexical Productivity and Written Codeswitching, Berlin/ New York: De Gruyter.

MERRIAM-WEBSTER. (2011): $\mathrm{Me}$ rriam Webster's Dictionary, URL: http://www.merriam- 
webster. com/ [Fecha de consulta $17 / 08 / 16]$.

REAL ACADEMIA ESPAÑOLA (2011): Diccionario de la Lengua Española, 22nd ed., URL: http://www.rae. es/rae.html [Fecha de consulta 17/08/16].

REAL ACADEMIA ESPAÑOLA: Banco de datos (CORDE) [online], Corpus diacrónico del español, http://www.rae.es [Fecha de consulta: 18/08/16].

RODRÍGUEZ GONZÁLEZ, F. (2003): "Pseudoanglicismos en el español actual. Revisión crítica y tratamiento lexicográfico", Revista española de lingüística, 43, pp.123-170.

SÁNCHEZ-BOUDY, J. (1999): Diccionario mayor de cubanismos, Miami: Ediciones Universal.
SÁNCHEZ FAJARDO, J. A. (2016a): "Usos figurados del léxico del béisbol en el español cubano", Punto y Coma, 146, pp. 19-23.

SÁNCHEZ FAJARDO, J. A. (2016b): "Anglicisms and calques in upper social class in pre-revolutionary Cuba: a sociolinguistic analysis", IJES, 16.1, pp. 3355.

SÁNCHEZ FAJARDO, J. A. (2017): $A$ dictionary of 1,000 loan words in Cuban Spanish with usages, synonyms, and etymologies, New York: Edwin Mellen Press.

SANTIESTEBAN, A. (1985): El habla popular cubana de hoy, La Habana: Editorial de ciencias sociales. 